Furthermore, they show that the system can be made both inherently safe and effective by using baffles inside and lagging on top of the humidifier, by thoroughly insulating the breathing tube, reducing the dead zone of the thermostat, and maintaining a water temperature only slightly above body temperature.

We thank Professor W. W. Mushin for his encouragement and constructive criticism.

\section{References}

Bushman, J. A., and Robinson, J. S. (1968). British fournul of Anaesthesia, 40, 796.

Kirch, T. J., and De Kornfield, T. J. (1967). Anesthesiology, 28,

Macintosh, R. R., Mushin, W. W., and Epstein, H. G. (1963). Physics for the Anaesthetist, 3rd edn. p. 54. Oxford. Blackwell Scientific Publications.

Spalding, J. M. L. (1956). Lancet, 2, 1140

Sykes, M. K. (1969). Anaesthesia, 22, 668.

\title{
Environmental Conditions and Body Temperatures of Elderly Women Living Alone or in Local Authority Home
}

\author{
CARMENCITA B. SALVOSA， P. R. PAYNE， ERICA F. WHEELER
}

British Medical fournal, 1971, 4, 656-659

\section{Summary}

The environmental and body temperatures of two groups of elderly women have been measured. One group was living in a local authority home (L.A.H.) and the others in their own homes in North London. The L.A.H. provided a constant environmental temperature which was at all times higher than that of the private houses. In the latter group the ambient temperature was higher in bed-sitting rooms than in houses with separate living rooms and bedrooms.

Body temperatures in summer were similar throughout both groups. In winter the skin and mouth temperatures of the subjects living independently were lower than those in the L.A.H.

Four subjects who had low mouth temperatures measured during two consecutive winters did not prove to have lowered deep body temperatures. The diet of these four subjects was similar in respect of all nutrients to that found in other groups of subjects of the same age, and in relation to published dietary standards was adequate in all respects.

\section{Introduction}

Accidental hypothermia is now recognized as a real hazard among the elderly population (Duguid et al., 1961; Prescott et al., 1962; Trafford and Hopkins, 1963; Rosin and ExtonSmith, 1964; Royal College of Physicians of London, 1966; Barley and Evans, 1970). The elderly people affected often live alone and in poor circumstances and by reason of accident, illness, or mental confusion are unable to call for assistance. In a survey among patients admitted to hospitals in England and Scotland the Royal College of Physicians found that there was a clear relationship between environmental temperature and the incidence of accidental hypothermia.

Fox et al. (1971) reported experiments which throw doubt on the significance of low oral temperatures measured in cool conditions. The reliance on mouth temperatures to diagnose hypothermia may in time lead to the condition being regarded

\footnotetext{
Department of Human Nutrition, London School of Hygiene and Tropical Medicine, London WC1E 7HT

CARMENCITA B. SALVOSA, B.S., M.S., Research Worker

P. R. PAYNE, B.SC., Senior Lecturer

ERICA F. WHEELER, M.PHIL., Lecturer
}

as so trivial and frequent an occurrence that seriously ill patients with a lowered deep body temperature might be overlooked.

The aim of the present study was to investigate body temperatures and the occurrence of hypothermia in elderly women living alone compared with those living in a local authority home (L.A.H.). Mouth temperatures were measured morning and evening and a continuous monitoring method (Humphrey and Wolff, 1968) was used to measure skin temperatures at two sites. In addition, environmental temperatures in the subjects' homes were continuously recorded.

\section{Subjects and Methods}

Forty women aged 69 to 93 years took part in the study. One group of 20 subjects lived independently in their own homes in North London. The other group of 20 were residents in an L.A.H. in Hertfordshire.

\section{FIRST STUDY}

The studies were carried out between February and June 1970. Measurements were made in North London during the cold months of February and March, and were repeated in May and June, when the weather was warmer. Measurements in the L.A.H. were done in April.

The following data were collected for each subject:

Anthropometric.-Height, weight, and skinfold thickness (triceps, biceps, subscapular, and suprailiac).

Skin Temperatures.-The "Temperature Socially Acceptable Monitoring Instrument" (Humphrey and Wolff, 1968) is a portable monitoring instrument giving an integrated average temperature over a measured period of time. This was used to record skin temperatures for 24 hours. Each subject was fitted with two instruments in the morning, one being attached to the side of the neck, in a position which was not covered by hair or clothes, and the other on the sternum under the clothes. The recording cells were changed in the evening so that day and night values were obtained separately.

Mouth Temperatures.-Sublingual temperatures were taken in the morning and in the evening of the days on which the instruments were being worn. A low-reading clinical thermometer was used and was kept in the subject's mouth for three minutes, or longer if this was necessary in order to obtain constant reading.

Environmental Temparatures.-A thermohygrograph, which continuously records dry-bulb temperature and humidity, was taken into the subject's home. Recordings were made in the living room during the daytime and in the bedroom overnight. The thermohygrograph was placed in a position convenient to the subject, usually equidistant from the windows and the source of heat. 
By inquiry and observation, information was obtained on each subject's type of house heating, clothes and blankets used in winter and summer, and other topics related to thermal comfort. These data have already been reported by Watts (1970).

\section{SECOND STUDY}

Three subjects were selected from the first study for follow-up during February and March 1971, because their mouth temperatures had been below $35^{\circ} \mathrm{C}$ in 1970 (Eddy et al., 1970). Two of these agreed to co-operate in a further study, as did two other subjects whose mouth temperatures had been slightly in excess of $35^{\circ} \mathrm{C}$. These four were considered to be potentially hypothermic. The method of Fox et al. (1971) was followed, which uses urine temperature as a measure of deep body temperature. Urine temperatures were taken on rising and during the time when the investigators visited the subject in the morning. Sublingual temperatures and the ambient temperatures of the dwellings were also recorded. In view of the possibility that the diet of hypothermic subjects could be providing insufficient energy, or be deficient in other nutrients, a seven-day weighed dietary intake survey was carried out for each subject. Nutrient intakes were calculated by the University of London computer (Pellett and Wheeler, 1965).

\section{Results of First Study}

Details of the age, height, and skinfold thickness of each subject are given in Table I. Despite the differences in thermal environment and daily habitual activity between the two groups of subjects, the heights, weights, and distribution of body fat as indicated by skinfold measurements were very similar.

TABLE I-Age and Anthropometric Measurements of Women Living Alone or in an L.A.H.

\begin{tabular}{|c|c|c|c|c|c|}
\hline & & & & Living at Home & Living in L.A.H. \\
\hline & & & & \multicolumn{2}{|c|}{ Mean Value \pm Standard Deviation } \\
\hline 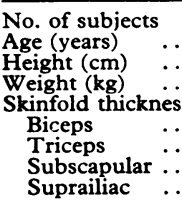 & $\begin{array}{l}\cdots \\
\cdots \\
\cdots \\
\cdots \\
\cdots \\
\cdots \\
\cdots\end{array}$ & $\begin{array}{l}\because \\
\therefore \\
\therefore\end{array}$ & $\begin{array}{l}\ldots \\
\cdots \\
\cdots \\
\ldots \\
\cdots \\
\cdots\end{array}$ & 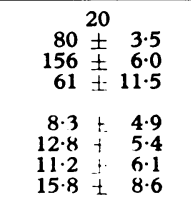 & $\begin{array}{r}20 \\
80 \pm 5.1 \\
157 \pm 6.5 \\
58 \pm 13.6 \\
(17 \text { subjects) } \\
8.3 \pm 4.8 \\
15.5 \pm 6.8 \\
14.8 \pm 9.7 \\
16.5 \pm 9.5\end{array}$ \\
\hline
\end{tabular}

ENVIRONMENT OF THE SUBJECTS

The L.A.H. was a modern, purpose-built, centrally-heated building provided with lifts. Meals, including coffee and tea, were served in a dining room, and during the day most of the residents sat in downstairs rooms. During the course of the study none of the subjects left the building. All but one of the private homes were situated in the adjacent North London districts of Kentish Town and Muswell Hill. Most of the housing in this area is terraced and between 60 and 100 years old. Six subjects each occupied an entire house, six lived in flats in converted houses, and eight occupied bed-sitting rooms. These dwellings have been classified into two types: " $A$ " dwellings which had separate bedrooms, and " $B$ " dwellings which had no separate bedrooms and where the subjects lived, slept, and often prepared meals in the same room. Flats and houses were included in the first category while bed-sitting rooms were considered in the second. All of the subjects went out to do their own shopping, and many made regular visits to friends and relatives.

\section{HEATING}

As expected, the centrally-heated L.A.H. had a constant ambient temperature of $17-20^{\circ} \mathrm{C}$, which varied little from winter to summer. Two of the private homes had central heating, and their temperature characteristics were similar to the L.A.H. The other 18 dwellings, however, had a variety of heating appliances which were turned on and off as needed. The effect of this heating pattern was most noticeable in the A dwellings, in which the bedrooms were heated for only an hour or two before use. The diurnal changes in temperature during summer and winter are shown for the two types of dwelling in Fig. 1. On average, the subjects living in A dwellings experienced a fall in temperature of $7.3^{\circ} \mathrm{C}$ on retiring.

It can be seen that in winter the ambient temperatures in both groups of dwellings were very variable; the mean night temperature of bedrooms in A dwellings $\left(8.9^{\circ} \mathrm{C}\right)$ was significantly lower than in $\mathrm{B}$ dwellings $\left(13.3^{\circ} \mathrm{C}\right)(\mathrm{P}<0.01)$ and the mean day temperature was $13.9^{\circ} \mathrm{C}$ in A living rooms, significantly below the mean of $16 \cdot 1^{\circ} \mathrm{C}$ for $\mathrm{B}$ rooms $(P<0.05)$. Both maximum and minimum temperatures showed the same $4-5^{\circ}$ differences between the two groups of dwellings. In summer time there were no significant differences in temperature between any of the homes.

\section{CLOTHING}

There was no difference in the amount of clothing worn by subjects in their own homes and in the L.A.H.

\section{BODY TEMPERATURES}

The mean values of temperature measurements at both positions on the skin and for the mouth are given in Table II, the subjects having been grouped according to type of dwelling. It can be seen that there were no large differences between the skin temperatures taken on the sternum and on the neck. However, the mouth temperatures were about a degree higher than those of the skin in all cases; and during the summer the mouth and

TABLE II-Mean Skin and Morning Mouth Temperatures of the Subjects $( \pm$ S.D.)

\begin{tabular}{|c|c|c|c|c|c|c|c|c|c|c|c|}
\hline \multirow{3}{*}{\multicolumn{2}{|c|}{ Site }} & \multicolumn{6}{|c|}{ Winter } & \multicolumn{4}{|c|}{ Summer } \\
\hline & & \multicolumn{2}{|c|}{ A Dwellings } & \multicolumn{2}{|c|}{ B Dwellings } & \multicolumn{2}{|c|}{ L.A.H. } & \multicolumn{2}{|c|}{ A Dwellings } & \multicolumn{2}{|c|}{ B Dwellings } \\
\hline & & Day & Night & Day & Night & Day & Night & Day & Night & Day & Night \\
\hline $\begin{array}{l}\text { Sternum } \\
\text { Neck } \\
\text { Mouth }\end{array}$ & $\begin{array}{l}. . \\
\cdots\end{array}$ & $\begin{array}{l}33.3 \pm 1.65 \\
33.4 \pm 1.26 \\
35.8 \pm 0.56\end{array}$ & $\begin{array}{l}34.7 \pm 0.82 \\
34.5 \pm 0.67 \\
35.9 \pm 0.70\end{array}$ & $\begin{array}{l}34 \cdot 2 \pm 0.78 \\
33 \cdot 8 \pm 0.98 \\
35 \cdot 2 \pm 0.99\end{array}$ & $\begin{array}{c}34 \cdot 4 \pm 0.99 \\
34.6 \pm 0.90 \\
36 \cdot 1^{*}\end{array}$ & $\begin{array}{l}34 \cdot 7 \pm 0.81 \\
34 \cdot 8 \pm 0.82 \\
36 \cdot 3 \pm 0.40\end{array}$ & $\begin{array}{l}35 \cdot 0 \pm 0.90 \\
35.0 \pm 1 \cdot 15 \\
36.4 \pm 0.52\end{array}$ & $\begin{array}{l}33.3 \pm 1.51 \\
34.0 \pm 0.75 \\
36.0 \pm 0.40\end{array}$ & $\begin{array}{l}34.7 \pm 0.95 \\
34.8 \pm 0.39 \\
36.2 \pm 0.71\end{array}$ & $\begin{array}{l}33.9 \pm 0.83 \\
34.5 \pm 1.40 \\
35.9 \pm 0.49\end{array}$ & $\begin{array}{l}35.0 \pm 0.70 \\
34.9 \pm 0.73 \\
36.4 \pm 0.42\end{array}$ \\
\hline
\end{tabular}

$P<0.01$ (sternum, winter, day) L.A.H. v. A dwellings.

$\mathrm{P}<0.05$ (sternum, winter, day) L.A.H. $v$. B dwellings.

P Only one value. 


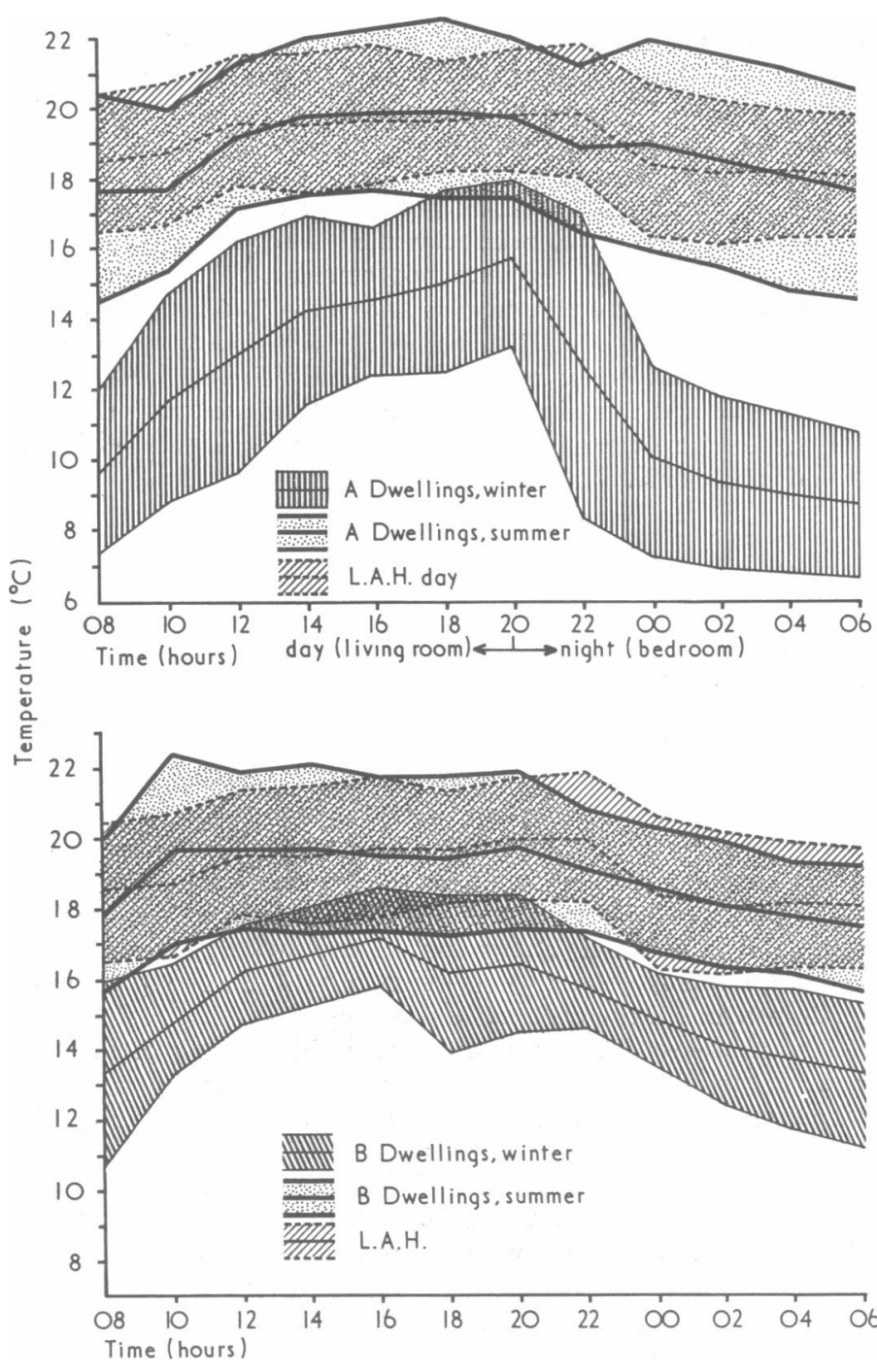

FIG. 1-Variation in room temperatures in A dwellings (above) and B dwellings (below).

neck temperatures were higher than in the winter. The L.A.H. group had higher average temperatures at all sites than the subjects living independently in their own home. In all groups the temperatures taken at night were somewhat higher than those found during the day.

In the L.A.H. group $80 \%$ of the subjects had sternum skin temperatures in the $34-36^{\circ} \mathrm{C}$ range during the daytime. The $B$ and A dwellings had $58 \%$ and $45 \%$ of the subjects respectively within this temperature range.

The distribution of subjects by temperature on the neck was similar to that by the temperature on the sternum. Most of the subjects living in A dwellings (81\%) were in the lower temperature ranges-that is between 30 and $34^{\circ} \mathrm{C}$. The $\mathrm{B}$ dwellings had a smaller percentage $(57 \%)$ in this range whereas the L.A.H. group had the lowest percentage, only $15 \%$ lying in the same range.

Table III shows the distribution of subjects by mouth temperature in winter. As might be expected, only one of the L.A.H. subjects had temperatures in the lower ranges-that is,

TABLE III-Distribution of Subjects by Morning Mouth Temperature (Winter)

\begin{tabular}{|c|c|c|c|c|c|c|}
\hline \multicolumn{4}{|c|}{ Temperature $\left({ }^{\circ} \mathrm{C}\right)$} & \multirow{2}{*}{$\begin{array}{c}\text { A Dwellings } \\
2 \\
0 \\
7 \\
1 \\
1\end{array}$} & \multirow{2}{*}{$\begin{array}{c}\text { B Dwellings } \\
1 \\
2 \\
1 \\
2 \\
1\end{array}$} & \multirow{2}{*}{$\begin{array}{c}\text { L.A.H. } \\
0 \\
1 \\
5 \\
7 \\
7\end{array}$} \\
\hline $\begin{array}{l}34 \cdot 5-35 \cdot 0 \\
35 \cdot 0-35 \cdot 5 \\
35 \cdot 5-36 \cdot 0 \\
36 \cdot 0-36 \cdot 5 \\
36 \cdot 5-37 \cdot 0\end{array}$ & $\begin{array}{l}\ldots \\
\cdots \\
\cdots\end{array}$ & $\begin{array}{l}\ldots \\
\cdots \\
\cdots\end{array}$ & $\begin{array}{l}\ldots \\
\cdots \\
\cdots \\
\cdots\end{array}$ & & & \\
\hline
\end{tabular}

between 34.5 and $35.5^{\circ} \mathrm{C}$-and none had temperatures of less than $35^{\circ} \mathrm{C}$. Of the 18 subjects living alone, however, three had mouth temperatures less than $35^{\circ} \mathrm{C}$, and would thus be conventionally classified as hypothermic.

\section{Results of Second Study}

\section{BODY TEMPERATURE}

During the second study the weather conditions were milder than in 1970, as shown by the fact that the average minimum day and night room temperatures were higher by $1.4^{\circ} \mathrm{C}$ and $3 \cdot 2^{\circ} \mathrm{C}$ respectively.

Table IV shows the mouth temperatures of the four subjects compared with those measured during the winter of 1970 . It

TABLE IV-Mouth and Urine Temperatures in 1971 of Four Subjects Who Had Low Mouth Temperatures in 1970

\begin{tabular}{|c|c|c|c|c|c|c|c|}
\hline \multirow{2}{*}{ Subject } & \multirow{2}{*}{$\begin{array}{c}\text { Type } \\
\text { of } \\
\text { Home }\end{array}$} & \multicolumn{3}{|c|}{ Mouth Temperatures $\left({ }^{\circ} \mathrm{C}\right)$} & \multicolumn{3}{|c|}{ Urine Temperatures, $1971\left(^{\circ} \mathrm{C}\right)$} \\
\hline & & $\begin{array}{l}1970 \\
\text { Summer }\end{array}$ & $\begin{array}{c}1970 \\
\text { Winter }\end{array}$ & $\begin{array}{r}1971^{*} \\
\text { Winter }\end{array}$ & On Rising & $\begin{array}{c}\text { Mid- } \\
\text { morning }\end{array}$ & Average \\
\hline $\begin{array}{l}\text { A } \\
\mathbf{K} \\
\mathbf{N} \\
\mathbf{R}\end{array}$ & $\begin{array}{l}\text { A } \\
\text { B } \\
\text { A } \\
\text { A }\end{array}$ & $\begin{array}{l}35.6 \\
36.2 \\
35.9 \\
36 \cdot 1\end{array}$ & $\begin{array}{l}34.9 \\
35 \cdot 7 \\
35.9 \\
34.7\end{array}$ & $\begin{array}{l}34.8 \\
35.9 \\
36.0 \\
34.9\end{array}$ & $\begin{array}{l}36 \cdot 3 \\
36.5 \\
36.4 \\
37 \cdot 0\end{array}$ & $\begin{array}{l}36 \cdot 3 \\
36 \cdot 7 \\
36.8 \\
36 \cdot 2\end{array}$ & $\begin{array}{l}36 \cdot 3 \\
36 \cdot 6 \\
36.6 \\
36 \cdot 6\end{array}$ \\
\hline
\end{tabular}

*Mean of four to six measurements taken on different days. Range of S.E. $\pm 3.8 \%$.

also shows their deep body temperatures, calculated as the mean value of two estimates of urine temperature. In all four subjects the mouth temperatures found in the winter of 1971 were the same as those in the winter of 1970 , whereas summermonth temperatures were on average $1^{\circ}$ higher. The deep body temperatures were always higher than the mouth temperatures, and were all very similar in value.

\section{DIETARY SURVEY AND ENERGY EXPENDITURE}

The results of the 1971 dietary survey of the four subjects are shown in Table V, with the measurements of energy expenditure made in 1970 (Payne, Wheeler, and Salvosa, 1971) and theenergy intake of the subject in 1968 or 1969 (Stanton and Exton-Smith, 1970). All the intakes of protein, minerals, and vitamins are above requirement levels; with the exception of niacin, all are above the levels recommended for the British population (Department of Health and Social Security, 1969).

TABLE v-Results of Dietary Survey

\begin{tabular}{|c|c|c|c|c|}
\hline Measurement & \multicolumn{4}{|c|}{ Subject } \\
\hline & $\mathbf{N}$ & A & $\mathbf{K}$ & $\mathbf{R}$ \\
\hline Intake $1968-9$ (kcal) & 2,330 & 1,915 & 1,719 & 1,520 \\
\hline $\begin{array}{l}\text { Expenditure 1970: } \\
\text { Summer (kcal) } \\
\text { Winter (kcal) }\end{array}$ & $\begin{array}{l}1,665 \\
1,828 \\
\end{array}$ & $\begin{array}{l}2,227 \\
2,357\end{array}$ & $\begin{array}{r}1,366 \\
934\end{array}$ & $\begin{array}{l}1,470 \\
1,528\end{array}$ \\
\hline 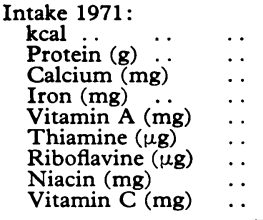 & $\begin{array}{c}1,748 \\
68 \\
946 \\
9 \cdot 8 \\
0 \cdot 95 \\
1,083 \\
1,597 \\
10 \cdot 1 \\
86\end{array}$ & $\begin{array}{c}1,652 \\
68 \\
862 \\
10 \cdot 4 \\
0 \cdot 71 \\
718 \\
1,322 \\
9 \cdot 6 \\
29\end{array}$ & $\begin{array}{c}1,783 \\
45 \\
763 \\
9 \cdot 4 \\
1 \cdot 01 \\
896 \\
1,156 \\
8 \cdot 4 \\
58\end{array}$ & $\begin{array}{c}1,385 \\
45 \\
603 \\
11 \cdot 9 \\
1 \cdot 33 \\
1,009 \\
1,432 \\
16 \cdot 9 \\
101\end{array}$ \\
\hline $\begin{array}{r}\text { Requirements (F.A.O., } \\
\text { 1957) (kcal) }\end{array}$ & 1,662 & 1,709 & 1,795 & 1,430 \\
\hline
\end{tabular}

The energy intakes seem to be somewhat low when compared with the U.K. recommended figures. When compared with the Food and Agriculture Organization (1957) recommendations, 
suitably corrected for weight and age, however, the 1971 intakes are adequate. In three subjects ( $\mathrm{A}, \mathrm{K}$, and $\mathrm{R}$ ) there was little difference between the 1968-9 and 1971 intakes, whereas subject N's intake was reduced in 1971.

The energy expenditures of $\mathrm{N}, \mathrm{K}$, and $\mathrm{R}$ were similar to their 1971 intakes; subject A's expenditure in 1970 was higher than her measured intakes.

\section{Discussion}

The object of this study was to make a controlled investigation of a group of subjects who because of their circumstances of life could be considered especially at risk from accidental hypothermia. Several of the subjects lived in old houses and used a miscellaneous range of home-heating methods. During the winter of 1970 temperatures as low as $8^{\circ} \mathrm{C}$ were recorded in living rooms and below $5^{\circ} \mathrm{C}$ in bedrooms in some of these houses. Temperature fluctuations were far greater in type A dwellings, in which the subject's bedroom was separate from the living room. The type $\mathrm{B}$ bed-sitting room accommodation provided a much more constant temperature, and was intermediate between type $\mathrm{A}$ and the centrally-heated L.A.H.

Incidence of Mouth Temperatures Less than $35^{\circ} \mathrm{C}$. - In the pilot surveys carried out in Redbridge and Barking by the Society of Medical Officers of Health (1969) the percentage of subjects found to have mouth temperatures below $35^{\circ} \mathrm{C}$ was $20 \%$ in one area and $4 \%$ in the other, the difference being partly explicable by the age of the subjects, who were on average older (all over 75 years) in the Redbridge group. In our small sample of 20 subjects three had winter-time mouth temperatures below $35^{\circ} \mathrm{C}$. The four subjects in the second study were found to have the same mouth temperatures in winter-time a year later, though in the intervening summer their mouth temperatures had risen by about $1^{\circ} \mathrm{C}$. For any one subject the measurements made on successive days were found to be consistent, with a standard error of between 3 and $8 \%$ for six occasions.

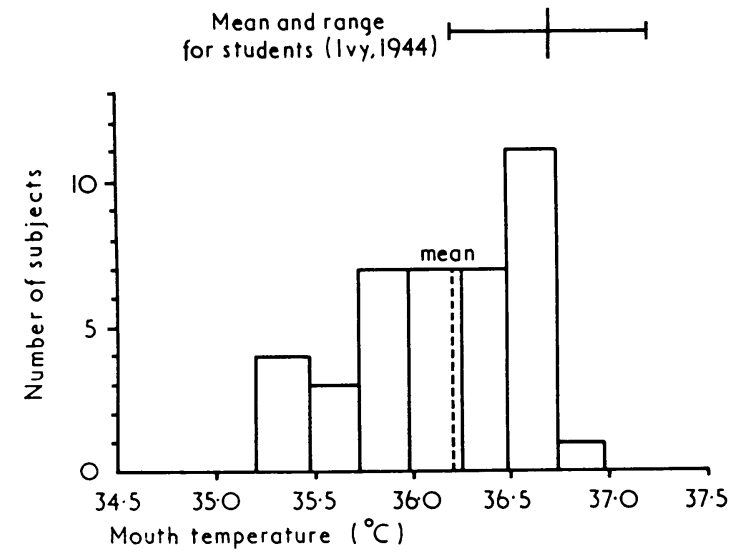

FIG. 2-Distribution of mouth temperatures in summer in $\mathbf{4 0}$ elderly women.

Mouth Temperatures of Subjects in a Warm Environment.The mean value of summer-time temperatures of the subjects living alone was the same as that of the subjects living in the L.A.H., though in the L.A.H. group the range was smaller. Accordingly the two groups have been combined in order to assess the range of normal variations in elderly women when the measurements are made under thermally comfortable conditions. The distribution of temperatures is shown in Fig. 2 together with the mean and range of mouth temperatures measured in students by Ivy (1944). The mean mouth temperature in the elderly women was $36 \cdot 2 \pm 0 \cdot 6^{\circ} \mathrm{C}$ compared with $36 \cdot 7 \pm 0 \cdot 22^{\circ} \mathrm{C}$ for the students, and this probably reflects a decline in body temperature with age, consonant with the changes which are known to occur in metabolic rate.

Measurement of Deep Body Temperature.-It is clear from Table IV that, in our four subjects, mouth temperatures measured in winter were consistently lower than urine temperatures. Mouth temperatures taken in summer were, however, close to winter urine temperatures. Whereas two of our subjects would have been classified as hypothermic, according to the B.M.A. (1964) memorandum, on the basis of repeated and consistent estimates of their mouth temperatures, this was not confirmed by their urine temperatures. We conclude that in these subjects low mouth temperatures are an indication of efficient conservation of deep body heat by reduction of peripheral circulation. Further studies will be needed to establish whether or not these subjects are those most at risk from the breakdown of thermoregulatory response, which is presumably the precursor of accidental hypothermia.

Energy Intake and Expenditure.-The four subjects showed no evidence of caloric or other dietary deficiency, and measures of their energy expenditure over 24-hour periods in 1970 corresponded reasonably well with their dietary energy intakes measured at various times between 1968 and 1971 .

We thank Miss B. Stanton for her help in contacting subjects, and Mrs. E. Roberts for her invaluable help in taking measurements. We are most grateful to our subjects for their enthusiastic co-operation; to the matron and staff of Torworth House, Boreham Wood, where a number of the subjects lived; to the Hertfordshire County Health and Welfare Department for making it possible for us to work at Torworth House; and to Pilkington Bros. Ltd. for financial help.

One of us (C.B.S.) is in receipt of a W.H.O. Fellowship.

\section{References}

Barley, S. L., and Evans, E. J. (1970). Lancet, 1, 1003.

British Medical Association (1964). British Medical fournal, 2, 1255.

Department of Health and Social Security (1969). Reports on Public Health and Medical Subjects, No. 120. London, H.M.S.O.

Duguid, H., Simpson, R. G., and Stowers, J. M. (1961). Lancet, 2, 1213.

Eddy, T. P., Payne, P. R., Salvosa, C., and Wheeler, E. F. (1970). Lancet, 2, 1088

Food and Agriculture Organization (1957). Calorie Requirements: Report of the Second Committee on Calorie Requirements. F.A.O. Nutrition Studies, No. 15. London, H.M.S.O

Fox, R. H., Woodward, P., Fry, A. J., Collins, J. C., and MacDonald, I. C. (1971). Lancet, 1, 424.

Humphrey, S. J. E., and Wolff, H. S. (1968). Fournal of Physiology, 194, 5P. Ivy, A. C. (1944). Quarterly Bulletin of Northwestern University Medical School, 18, 22.

Payne, P. R., Wheeler, E. F., and Salvosa, C. B. (1971). American fournal of Clinical Nutrition, 24, 1168.

Pellett, P. L., and Wheeler, E. F. (1965). Proceedings of the Nutrition Society,

24, xli.
Prescott, L. F., Peard, M. C., and Wallace, I. R. (1962). British Medical Fournal, 2, 1367.

Rosin, A. J., and Exton-Smith, A. N. (1964). British Medical fournal, 1, 16. Royal College of Physicians of London (1966). Report of the Committee on Accidental Hypothermia.

Society of Medical Officers of Health (1969). Public Health, 82, 223.

Stanton, B., and Exton-Smith, A. N. (1970). A Longitudinal Study of the Diets of Elderly Women. King Edward's Hospital Fund for London.

Trafford, J. A. P., and Hopkins, A. (1963). British Medical fournal, 1, 400.

Watts, A. J. (1970). Research Report on Some Social and Psychological Aspects of the Thermal Environment of Old People. Medical Council Environmental Physiology Unit, London School of Hygiene and Tropical Medicine. 